\title{
Health vs. Disease in the Context of Verbalization of the Axiological Picture of the World of a Modern Doctor
}

\section{Здоров'я vs. хвороба в контексті словесної репрезентації ціннісної картини світу сучасного лікаря}

\author{
Tetyana Leshchenko \\ Ph.D. in Philology, \\ Associate Professor, Heard of \\ the Department of Ukrainian Studies \\ and Humanitarian Training
}

\author{
Тетяна Лешенко \\ кандидат філологічних наук, \\ доцент, завідувачка кафедри \\ українознавства та гуманітарної \\ підготовки
}

E-mail: tetyana.57@ukr.net orcid.org/0000-0003-4682-3734

Maryna Zhovnir

Ph.D. in Philology, Lecture
Марина Жовнір

кандидат філологічних наук, викладач

E-mail: m.zhownir@gmail.com orcid.org/0000-0001-8498-9802

HSEE of Ukraine "Ukrainian Medical Stomatological Academy»

23, Shevchenko Str., Poltava, Ukraine, 36011
ВДНЗУ «Украӥнська медична стоматологічна академія»

$\checkmark$ вул. Шевченка, 23, м. Полтава,

Україна, 36011

Original manuscript received March 12, 2018

Revised manuscript accepted October 13, 2018

\section{ABSTRACT}

The article is devoted to the problem of linguistic interpretation of values and anti-values. The relevance of their differention and the functioning of dichotomy value - anti-value is pointed out.

It is defined that values are a complex of vital material and spiritual, non-material concepts that outline the basic behavioral dominant of a person, 
provide their main interests and essential needs. At the same time, anti-values are defined as the opposition (meaning) to values as universal category of the general human axiological paradigm.

Considering the value aspects of medical communication, presently great attention is paid to the importance of studying doctor's axiological continuum. In this work health and disease were defined as the principal semantic oppositions. According to the results of analysis, these contrast notions are central to the axiological picture of the modern doctor, and these concepts belong to different parts of the coordinate system - value - antivalence. The author substantiates the opinion that the value for the doctor means the specific notion directed him to be an competent expert in the medical field, an essential attribute of consciousness that determines main vectors of his professional activity.

The study of the discourse-textual material made it possible to determine the language reflexes of these values. The paper presents features of the language objectification of opposing axiological landmarks - health and disease. It is indicated that all analyzed verbal objectivists reflect a modification of the health paradigm. In addition, the pragmatic potential of tokens is noted, which verbalize the value component of medical communication. The positive and negative connotations recorded in the discourse express the approval, affability, reproach or critical attitude of the doctor to the patients.

Key words: axiological linguistics, value, anti-values, medical discourse, doctor, health, illness.

\section{Вступ}

Зміна панівної загальнонаукової системно-структурної парадигми на антропоцентричну, статичної на динамічну вплинула на зрушення у філологічній царині. Проблеми людиноорієнтованості наразі стрижневі в лінгвістиці. У полі зору мовознавців, зокрема лінгвокультурологів, - дослідження тісного зв'язку мови, духовних і матеріальних надбань людства, пошук їх перетинів та взаємовпливів. Такий зв'язок беззаперечний і зумовлює появу позамовних рефлексів у лінгвальній площині. У контексті актуальних мовознавчих ідей цікавість викликає мовна об'єктивація цінностей як стрижневих характеристик культури й ментальності.

Стрімке посилення наукового інтересу до вербалізації поведінкових стандартів та ідеалів посприяло розвитку нового відгалуження філології - аксіологічної лінгвістики, теоретичні й методологічні підвалини якої уже сформовані як у західному, так 
і в східнослов'янському мовознавстві (Арутюнова, 1984, 1988; Вдовиченко, 2006; Баранов, 1989; Барышков, 2005; Дементьев, 2013; Ивин, 2006; Ильин, 2005; Капанадзе, 1988; Карасик, 1996, 1998, 2004; Космеда, 2000; 2001; Маслова, 2011; Слишкин, 2001; Фрумкина, 2001; Van Dijk, 2008; Gurevich, 2000; Donaldson, 1996; Lindsay, 2000 та ін.). У мовознавчих дослідженнях репрезентовано й досить повно описано мовну особистість різних комунікативних парадигм. Це тісно пов'язано 3 новим дослідженнями в галузі психолінгвістики (Балабан, 2017; Ігнатьєва, 2017; Компанцева, 2018; Кузнєцова, 2012; Green, 2014; Orman , 2016; Saarni, 2011; Yancey, 2014 та ін.).

Уживання під час спілкування лінгвознаків, які виражають національно-культурні й особистісні аксіологічні орієнтири, специфікує спілкування і чи не найповніше відтворює ціннісний обшир учасників інтеракції. 3 одного боку, дискурс містить відображення світу моралі, доброчесності та внутрішньої чистоти, що вважаються мірилом духовного багатства особистості, а 3 іншого - увиразнює переплетення матеріальних і життєдайних благ, які забезпечують повноцінність людського буття. Репрезентація i ранжування цінностей на дискурсивному рівні сприяють дослідженню аксіологічної шкали його учасників і структуризації парадигми біполярних категорій, іменованих антицінностями (нецінностями).

Сучасні мовознавці активно досліджують аксіологічні тезауруси різних дискурсивних моделей. Кожен тип дискурсу потребує грунтовного й детального опису з огляду на вияв особливостей комуніканта i його вплив на процес спілкування (Вдовиченко, 2006; Дементьев, 2013; Карасик, 1998; 2004; Космеда, 2000, 2001; Краснобаєва-Чорна, 2006, 2008; Маслова, 2011; Омельченко, 2007, 2009; Онищенко, 2005; Самохіна, 2007; Соловйова, 2007; Славова, 2012; Тараненко, 2004 та ін.)

Прикметно, що проблема медичної комунікації також стає гостро актуальною. 3 огляду на це, важливим бачиться розгляд у контексті мовознавства ціннісної компоненти дискурсу сучасної медицини. Водночас, зважаючи на те, що «Кожна цінність характеризується наявністю однієї чи кількох антицінностей» (Вдовиченко, 2010: 57), вичерпному аналізу поліхромної аксіологічної палітри розглядуваного дискурсу, на нашу думку, 
Здоров'я vs. хвороба в контексті словесної репрезентації иіннісної...

сприяє студіювання діаметрально протилежних життєвих орієнтирів, адже саме їх функціонування в комплексі виформовує аксіологічний кодекс мовця загалом та лікаря зокрема.

Україністика наразі, на жаль, не має грунтовної праці, присвяченої ціннісним аспектам медичної комунікації, зокрема опису прояву аксіологічного континууму лікаря в лексичному ярусі сучасної української мови.

У цьому, як на нас, і полягає своєчасність та актуальність пропонованої наукової студії.

Мета - дослідити особливості лексичної об'єктивації бінарної аксіологічної опозиції здоров'я - хвороба в мовленні сучасного лікаря. Для досягнення зазначеної мети необхідно виконати низку завдань:

- з'ясувати місце аксіологічно орієнтованих студій у мовознавчій науці;

- інтерпретувати цүінності та антищінності в лінгвістичному контексті;

- проаналізувати словесні репрезентанти дихотомії здоров'я хвороба в медичному дискурсі.

Наукова новизна дослідження полягає передовсім у тому, що в ньому вперше здійснено спробу проаналізувати елементи словесної репрезентації ціннісної дихотомії здоров'я - хвороба в медичному дискурсі, представленому в мережевому контенті.

Теоретична цінність статті полягає в тому, що іiі висновки й положення збагатять новими ідеями вітчизняну лінгвоперсонологію, дискурсологію, психолінгвістику, комунікативну лінгвістику. Виявлені і проаналізовані ціннісні вектори віртуального лікаря будуть посутнім внеском у формування поняття мовленнєвої особистості сучасного лікаря.

Практичне значення цієї наукової студії полягає в тому, що матеріали праці можуть бути використані у процесі підготовки занять із сучасної української мови, розробки спецкурсів когнітивної лінгвістики, культури мовлення, соціолінгвістики, психолінгвістики, лінгвоперсонології та ін. Прислужиться представлені у статті інформація також у науково-пошуковій роботі студентів, магістрантів та аспірантів. Цілком можливо, репрезентовані в розвідці результати зацікавлять лікарів. 
Health vs. Disease in the Context of Verbalization of the Axiological...

Матеріалом дослідження слугувати комунікативні фрагменти, представлені на «Українському форумі лікарів» (загальний обсяг понад 5000 зразків). Тож зауважимо, що об'єкт опису в цій статті - мовленнєва особистість віртуального лікаря, парадигма аксіологічних орієнтирів якого виявляється в мережевому контенті.

\section{Методи дослідження}

У праці використано і загальнонаукові, і власне лінгвістичні методи та прийоми. Описовий метод із прийомами спостереження, зіставлення й узагальнення застосовано для аналізу фактичного матеріалу та систематизації мовних явищ. За допомогою методу когнітивного аналізу з'ясовано аксіологічні орієнтири лікарів. Дефініційно-компонентний аналіз ужито для встановлення значень розглядуваних словесних репрезентантів, контекстуальний для виявлення мовних засобів експлікації цінностей. Методика дискурс-аналізу дала змогу дослідити позалінгвальну зумовленість словесних виявів.

\section{Результати дослідження}

Цінність для лікаря - це те, на що скерована його робота як фахівця медичної галузі, невіддільний атрибут людської свідомості, який окреслює вектори його професійної діяльності. Вибудувана під впливом екстрамовних чинників система поглядів, ідей i переконань, що набули статусу базових завдяки спромозі посприяти досягненню особистих надзавдань, не лише заманіфестовує сприйняття навколишнього світу, ставлення до нього, а й окреслює поведінкові та комунікативні домінанти мовця.

В.А. Маслова вбачає особливість людини в здатності оцінювати факти, їхнє значення та реалізовувати ціннісне ставлення до світу (Маслова, 2011: 386). «Ми переконані, що мовна картина світу виокремлюється разом із ціннісною», - зауважує В.I. Карасик (Карасик, 1996: 5). Звісно, обидві зафіксовані у свідомості мовців й об'єктивуються на мовному рівні. Знакове втілення мають і поняття, які спростовують ту чи ту цінність, i, цілком вірогідно, займають місце поміж компонентів «мова - людина - ціннісна свідомість культура» (Светоносава, 2006: 32). Йдеться про аксіологічно маркіровані слова, що перебувають в антонімічних відношеннях 
Здоров'я vs. хвороба в контексті словесної репрезентації иіннісної...

iз номінаціями цінностей i вживаються для вираження ціннісно протилежних понять.

Нині активно дискутується питання про те, як пов'язані омовлені суб'єктивні характеристики оцінюваного. Видається, що мають рацію науковці, які наполягають на істинності й повнокровності функціювання дихотомії изінність - антицінність (нецінність) і цим окреслюють межі наукового студіювання тісї чи тієї аксіологічної парадигми (Вдовиченко, 2006; Дементьев, 2013; Карасик, 1998; 2004; Космеда, 2000, 2001; Краснобаєва-Чорна, 2006, 2008; Маслова, 2011; Славова, 2012 та ін.)

«Цінність для людини - це все, що є важливим для неї, має особистий та загальний смисл. Із цінностями ми маємо справу тоді, коли йдеться про щось рідне, святе, краще, дороге, досконале... », переконана В.А. Маслова (Маслова, 2011: 386). Тож цінності - це сукупність життєво необхідних матеріальних чи ідеальних понять, які регулюють поведінку людини, забезпечують їі основні інтереси та потреби. Водночас антицінності - опозиційна (за смислом) до цінностей універсальна категорія аксіологічної парадигми.

Уважаємо, що цінності мають лише позитивні вияви та можуть інтерпретуватися особистісною рецепцією задекларованих загалом соціально-культурних норм, ідеалів і стандартів. Кваліфікаційна риса таких аксіологічних зразків, як на нас, - значущість i позитивне спрямування, антицінностей - негативне.

Дослідженню проблематики статті сприяє якнайповніше опрацювання наукових студій, присвячених різноаспектному розгляду медичного дискурсу. Екстраполювавши теоретичні зауваги на обстежені фрагменти живого мовлення в лікарському середовищі, вирізняємо ключові семантичні опозиції - здоров'я - хвороба, які за результатами аналізу посідають чільне місце в аксіологічній картині світу сучасного лікаря та займають діаметральні позиції на осі цінність - антицінність.

Безперечно, стрижнем повсякчасного функціонування людської спільноти є життя. У цьому контексті здоров'я - це найважливіше поняття для людини, що має пріоритет поміж інших у загальному континуумі iї буттєвих ідеалів i стандартів. Не викликає щонайменших сумнівів вагомість для гармонійного людського існування фізичної дужості та внутрішньої сили й енергії. В «Етичному кодексі лікаря України» занотовано: «Діяльність 
Health vs. Disease in the Context of Verbalization of the Axiological...

лікаря спрямована на захист інтересів пацієнтів (суб’єкта діяльності у сфері охорони здоров'я) та життя суспільства в цілому, визначає можливість задоволення головних потреб і прагнень у збереженні життя та здоров'я» (ЕКЛ, 2000: 6). У межах інституту охорони здоров’я утрадиційнено думку про те, що розглядувана цінність засаднича для того, хто лікує хворих, скеровує професійну діяльність на збереження, зміцнення чи відновлення здоров'я та цілісності людського організму.

«Важко переоцінити значення слова в стосунках лікаря i хворого. Словом можна не тільки спричинити функціональні зміни в організмі, а навіть призвести до летальних наслідків», зауважує Т.О. Лещенко (Лещенко, 2017: 7). Першочергове завдання лікаря - допомога хворому. Така мета детермінує поведінку фахівця медичної галузі й транслюється в дискурсі. Об’єктивація ціннісних домінант відбувається на будь-якому мовному рівні. У досліджуваному матеріалі той чи той аксіологічний орієнтир, безперечно, проявляється в сукупності слів. 3-поміж лексичних засобів експлікації «стану організму, при якому нормально функціонують усі його органи» (СУМ, 1970: 547), вирізняється високочастотний словесний репрезентант базової людської цінності - лексема здоров'я: «Щоб поширювати інформацію про стан здоров'я - необхідна письмова згода пацієнта».

Навколо нього зосереджуються лексеми-експліканти, утворені внаслідок розширення його семантики, зокрема оздоровлення, лікування, зиілення, відновлення, реабілітацуія, терапія тощо, які об’єднані інтегральною семою «поліпшувати, поправляти стан чийого-небудь здоров'я; робити здоровим, здоровішим» (СУМ, 1970: 652): «Зокрема, у містечку Ірпінь уже створено повноцінну клініку на 70 ліжск, де пройдуть курс оздоровлення військовослужбовці, які зазнали загальносоматичних поранень», «Медпрацівник не Бог - людина, але від нього, як від Бога, для зиілення украй потрібна недужим людям допомога», "Хоча щуодо раку стравоходу $\epsilon$ різні точки зору. Зокрема, на останньому гастротижні в США була доповідь про хороші результати його лікування $і$ відновлення прохідності иляхом брахітерапї̈.

На основі спільних сем асоціативно наближеною є лексема здоровий, кодифікована зі значенням «який має здоров'я; непошкоджений; міцної будови; сильний, дужий» (СУМ, 1970: 546): 
Здоров'я vs. хвороба в контексті словесної репрезентації иіннісної...

«Написали йому довідку, мовляв, множинні забої, необхідності госпіталізачії а стацуінар немає, практично здоровий», «Одна чистка зубів ультразвуком, десять масажів за 600 у. о. i ти здоровий!».

Повсякчас актуалізовано в дискурсі слова, що формують парадигму синонімічних зв'язків до вказаного атрибутива здоровий (бадьорий, міцний, стійкий, сильний, дужсй, могутній, повносилий, витривалий, дієздатний та ін.): «Це дало підстави припустити, щуо ліпше штучно заразитися, обравши для цзього час, коли організм особливо сильний $i$ тому має більше шансів щзасливо перенести хворобу».

Окреме місце поміж об’єктиваторів досліджуваної цінності посідають вербалізми, у конотативному макрокомпоненті яких зафіксовано семи, що виражають загальне значення «ставати здоровим, поправлятися після хвороби, поранення» (СУМ, 1970: 393): здоровити, здоровіти, одужувати, видужувати, поправлятися, виліковуватися, підліковуватися, відновлюватися тощо: «Допоможімо Олександру одуюсати!», «Потихеньку потрібно відходити від дофаміну з щоденним зниженням дози $і$ все повинно відновитися», «У неї не було шансів вилікуватися самостійно в проміжку між операціями».

Належний фізичний, психічний, духовний та соціальний стан - запорука повноцінного життя людини. Основними завданнями професійної діяльності спеціаліста медичної галузі $\epsilon$ допомога пацієнтам, відновлення й зміцнення їхнього здоров'я, діагностування, лікування і запобігання хворобам. Після ретельного обстеження стану хворого лікар розробляє ефективну (на його думку) схему лікування, націлену на повне одужання. Тож активна й виважена боротьба 3 хворобою та іiі проявами - це пріоритет фахової діяльності всіх працівників інституту охорони здоров'я. Спостережено в дискурсі мовні рефлекси вказаних професійних цілей і надзавдань лікаря.

Досліджувані комунікативні фрагменти містять парадигму семантично близьких номенів, ужитих на позначення «порушення нормальної життєдіяльності організму під впливом несприятливих чинників внутрішнього й зовнішнього середовища» (СУМ, 1970: 47). Слова-репрезентанти стрижневої антицінності, узуальні синоніми захворювання, недуга, неміч, нездужання, нездоров'я, 
хворість, слабість тощо фіксують розширення семантики лексеми хвороба й указують на бачення лікарями проблеми, усвідомлення шкідливої дії аномальних, часом патологічних, фізичних та емоційних станів на людський організм, а також посвідчують потребу нівелювати їхні можливі наслідки. Актуалізація в дискурсі вказаної синонімічної парадигми пересвідчує у тому, що лікарі адекватно розмежовують різні відхилення в організмі людини від загальноприйнятої норми: «B анамнезі гіпертонія та імемічна хвороба серия», «Постназальне затікання $і$ гастроезофагеальна хвороба викликають факультативну обструкиію дихальних шляхів $i$ кашель після іжі і в положенні лежачи, щуо часто супроводжується печією», "3'явилася слабкість, нездужання, біль у суглобах, субфебрильна температура в денні години».

Дериваційний потенціал лексеми хвороба фіксує субстантив хворий, актуалізований в обстежених фрагментах зі значенням «який має яку-небудь хворобу, нездужає; нездоровий; протилежне здоровий; який свідчить про поганий стан здоров'я людини, наявність у неї якоїсь хвороби» (СУМ, 1970: 46). Експлікує стрижневу сему й номен пащієнт - «хворий, що звертається до лікаря» (СУМ, 1970: 102). «Висновок - пацієнт помер 3 невідомих причин на фоні шоку неясної етіологї», «На жаль, пацієнт (і лікарня) не має можливості провести контрольне КТ дослідження при виписиі».

Зауважмо активність функціонування в медичному дискурсі лексеми пац̧ієнт, яка, на відміну від хворий, місткіша за значенням, адже вказує не лише на біологічні девіації, а й на правовий статус недужої людини.

Спостерігається модифікація парадигми в галузі охорони здоров'я, зокрема трансформація в узуальній моделі спілкування та взаємин «лікар - пацієнт» - пасивність пацієнта у відповідальності за своє здоров'я та його цілковите підпорядкування лікареві віднині змінюється на активність і залучення до прийняття рішень того, хто отримує медичну допомогу. Це зумовлює появу в дискурсі номінації клієнт: "Якщо иче ПАЦІЕНТ - треба робити те, щзо правильним вважає лікар. Якщчо ие кЛІЕНТ - то клієнт завжди правий, тобто облизувати його треба з усіх боків (щуоб він залишив вам свої гроші). Прикметно, що синонімічну заміну чи навперемінне послуговування обома лексичними одиницями поєднано 3 
Здоров'я vs. хвороба в контексті словесної репрезентації иіннісної...

уживанням лексеми клієнт із відчутним негативним маркуванням: «Клієнт досвідчений, умудряється через черевну стінку повністю просунути голку в черевну порожнину».

Полярними до гармонійного (духовного й тілесного) стану людини вважаються такі, що супроводжуються будь-якими хворобливими проявами чи відчуттями. Симптоми аномалій розвитку й життєдіяльності людського організму стають наслідками порушень оптимального перебігу фізіологічних процесів (фізичне здоров'я), соціальної активності й адаптації (соціальне здоров'я), консонансу психічних станів і функцій (психічне здоров'я), позитивно емоційної та когнітивної самооцінки (духовне здоров’я). Неузгодженість функціонування організму репрезентовано на мовному рівні низкою атрибутивів, між якими виникають парадигматичні відношення синонімії (хворий, нездоровий, недужий, слабий, кволий, неміцуний, недужий, млявий, в'ялий, немічний, плохий, ослаблений, слабосилий та ін.): «В периу чергу, винуватцุем передчасної смерті $\epsilon$ нездоровий спосіб життя даниів: дуже велика поширеність куріння та споживання алкоголю...».

Вагомими словесними ресурсами вираження антицінності хвороба є вербалізми хворіти, недужати, нездужати, слабувати, слабіти та ін.: «А адже кожен з нас мріє прожити якомога довше, а хворіти якомога менше», "Так щзо ризик захворіти в дитячому відділенні мінімальний». У мовленні лікаря вони відображають стан страждання пацієнта від якогось недугу, що руйнує змодельовану ідеалістичну картину фізичного та психічного балансу людського життя. Утім, указана парадигма, безперечно, увиразнює апріорні закони функціонування всіх живих організмів на векторі життя - смерть.

\section{Висновки}

Отже, цінність - це надважливе поняття, яке окреслює людську сутність, а система цінностей $є$ невід'ємним атрибутом людської свідомості. Мова, що безперервно взаємодіє з культурою i мисленням, виформовує особистість, номінуючи й употужнюючи iii домінантну аксіологічну парадигму, моральні та поведінкові стереотипи, принципи, які регулюють ставлення до себе й оточуючих людей. 
Health vs. Disease in the Context of Verbalization of the Axiological...

Ціннісний континуум медичної комунікації дотепер мало вивчений. У проаналізованих зразках медичного дискурсу актуалізуються інтерпретовані лікарем парадигми соціальнокультурних норм i стандартів. Аналіз мовленнєвої особистості сучасного віртуального працівника медичної галузі дав змогу виявити елементи репрезентованої в мережевому контенті аксіологічної шкали лікаря, а також посприяв висвітленню питання омовлення опозиційної (за смислом) до цінностей системи універсальних категорій - антицінностей.

3'ясовано, що центральну позицію в загальній системі життєво необхідних для лікаря матеріальних та ідеальних понять займають ті, що тісно пов'язані зі здоров'ям людини. Це посвідчує висока частотність послуговування лексемами здоров'я й асоціативно наближеними до неї, зокрема атрибутивами та вербалізмами, об'єктиваторами належного фізичного, психічного, духовного та соціального стану і повнокровного життя людини.

Зафіксовані семантично близькі номени на позначення різних проявів порушення нормальної життєдіяльності людини та відхилення в іii організмі від загальноприйнятої норми увиразнюють низку антицінностей сучасного віртуального лікаря. Установлено, що репрезентанти стрижневої антицінності - лексеминомінації аномальних, патологічних, фізичних та емоційних станів людського організму.

Зауважено, що доповнюють аксіологічну палітру сучасного лікаря номінації учасників комунікації в межах узуальної дихотомії «лікар - пацієнт». При цьому акцентовано на рольових трансформаціях у названій традиційній моделі спілкування. Аргументовано з'яву й употужнення позицій в медичному дискурсі номінації клієнт:

У проаналізованих зразках медичного дискурсу зафіксовано наявність конотативно маркірованих словесних одиниць, які, 3 одного боку, експлікують ставлення лікаря до омовленого, а 3 іншого - мають потужний прагматичний потенціал.

Доведено, що доброзичливість, схвалення, привітність або докір чи різкий осуд, які можуть виражати позитивно й негативно навантажені лексеми, доповнюються реалізацією прагматичного заряду у висловленні та, на нашу думку, можуть стати об'єктом окремого наукового дослідження. 
Здоров'я vs. хвороба в контексті словесної репрезентації иіннісної...

Запропонована наукова розвідка - це лише спроба описати ціннісні вектори сучасного віртуального лікаря. Інформація, представлена у статті, безумовно, не вичерпує всіх можливих аспектів вивчення його аксіологічного континууму. У перспективі бачиться представлення експериментального матеріалу. Науково актуальним уважаємо також поглиблене студіювання аксіологічної картини світу сучасних лікарів на ширшому дискурсивному матеріалі із залученням соціолінгвістичних, психолінгвістичних $\mathrm{i}$ статистичних методів дослідження.

На часі - скрупульозне студіювання об'єктивації аксіологічної парадигми лікаря на мовному рівні - лексичному, морфологічному, фразеологічному, синтаксичному.

\section{Література}

Анипкина Л.Н. Оценочные высказывания в прагматическом аспекте. Филологические науки. 2000. № 2. С. 58-65.

Арутюнова Н.Д. Аксиология в механизмах жизни и языка. Проблемы структурной лингвистики 1982. Москва: Наука, 1984. С. 5-23.

Арутюнова Н.Д. Типы языковых значений. Оценка. Событие. Факт. Москва: Наука, 1988. 338 с.

Баранов А.Н. Аксиологические стратегии в структуре языка (паремиология и лексика). Вопросы языкознания. 1989. № 3. С. 74-90.

Балабан О.О. Поняття ментального лексикону та моделі організації знань у пам’яті людини. Психолінгвістика. 2017. № 21 (2). С. 12-26.

Барышков В.П. Аксиология личностного бытия. Москва : Логос, 2005. 192 с.

Вдовиченко Л.В. «Порядок» и «беспорядок» как и антиценность в политическом дискурсе России и США. Политическая лингвистика. № 3 (33). Екатеринбург, 2010. С. 57-61.

Дементьев В.В. Коммуникативные ценности русской культуры : категория персональности в лексике и прагматике : монография. Москва : Языки славянской культуры, 2013. 337 с.

ЕКЛ, 2000 : Етичний кодекс лікаря України. Медицина транспорту України. 2000. № 4. С. 6-11.

Ивин А.А. Аксиология. Москва : Высшая школа, 2006. 390 с.

Ігнатьєва C.C. Функціональні особливості емоційної пам'яті в структурі щоденникового дискурсу. Психолінгвістика. 2017. № 22 (2). С. 62-72.

Ильин В.В. Аксиология. Москва : Изд-во МГУ, 2005. 216 с.

Карасик В.И. Аксиологическая лингвистика: концепты и дискурс. Германистика в России: традиции и перспективы. Новосибирск : Изд-во НГУ, 2004. C. $28-32$.

Карасик В.И. О категориях дискурса. Языковая личность : соииолингвистические u эмотивные аспекты. Волгоград : ВГУ. Саратов: СГУ, 1998. С. 185-197.

Карасик В.И. Языковая личность : культурные концепты. Волгоград, Архангельск : Перемена, 1996. 260 с.

Капанадзе Л.А. Способы выражения оценки в устной речи. Разновидности городской устной речи. Москва : Наука. 1988. С. 151-156. 
Health vs. Disease in the Context of Verbalization of the Axiological...

Караулов Ю.Н. Русский язык и языковая личность. Москва : Наука, 1987. 261 с.

Компанцева Л.Ф. Психолінгвістичний опис технологічного дискурсу нових медіа. Психолінгвістика. 2018. № 23 (2). С. 120-131. doi.org/10.5281/zenodo.1208639

Космеда Т.А. Аксіологічні аспекти прагмалінгвістики: формування i розвиток категорії оцінки. Львів : Вид-во ЛНУ ім. І.Франка, 2000. 349 с.

Краснобаєва-Чорна Ж. Дискурсивна практика. Донецьк : ДонНУ, 2008. 141с.

Краснобаєва-Чорна Ж. Термінополе концепт. Украӥнська мова. 2006. № 3. С. 67-79.

Кузнєцова Т.В. Аксіологічні моделі мас-медійної інформації : монографія. Суми : Університетська книга, 2010. 279 с.

Кузнєцова Т.В. Мова як детермінант аксіологічного балансу в інформаційному просторі. Психолінгвітика. 2012. Вип. 10. С. 286-294.

Лещенко Т.О. Українська мова в медицині. Полтава : ТОВ «АСМІ», 2017. 258 с.

Маслова В.А. Концепты и ценности: содержание понятий, языковая интерпретация. Ученье записки Таврического национального университета им. В.И. Вернадского. 2011. № 2. С. 383-387.

Омельченко Л.Ф. Аксіологічний аспект телескопії в англомовному дискурсі. Іноземна філологія. № 6. С. 13-26.

Омельченко Л.Ф. Культурно-національні конотації англійських композит. Новітня філологія. Миколаїв : Вид. МДГУ ім. Петра Могили, 2007. С. 74-86.

Онищенко О.В. Категорія оцінки та засоби іiі вираження в публіцистичних та інформаційних текстах : автореф. дис. ... канд. філол. наук : 10.02.01. Дніпропетровськ, 2005. 20 с.

Островська О.М. Лінгвостилістичні засоби реалізації категорії оцінки (на матеріалі американської художньої прози) : автореф. дис. ... канд. філол. наук: 10.02.04. Львів, 2001. 20 с.

Светоносова Т.А. Сопоставительное исследование ценностей в российском и американском политическом дискурс : дисс. ... канд. филол. наук : 10.02.20. Екатеринбург, 2006. 174 с.

Славова Л.Л. Мовна особистість лідера у дзеркалі політичної лінгвоперсонології: США - Україна. Житомир : Вид-во ЖДУ, 2012. 360 с.

Слышкин Г.Г. Аксиология языковой личности и сфера аксивной лингвистики. Социальная власть языка. Воронеж : Изд-во ВГУ, 2001. С. 53-64.

Соловйова Л.Ф. Вираження аксіологічних категорій у сучасній англійській мові (атрибутиви, предикативи і релятиви оцінки) : автореф. дис. ... канд. філол. наук: 10.02.04. Харків, 2000. 20 с.

СУМ, 1970: Словник української мови : в 11-ти т. Київ : Наукова думка, 1970. 1980.

Тараненко О.О. Формування нової системи соціальних цінностей і пріоритетів українського суспільства (на матеріалах української мови кінця XX початку XXI ст.). Мовознавство. 2004. № 3. С. 3-33.

Фрумкина Р.М. Психолингвистика. Москва : Наука, 2001. 218 с.

Уфимцева Н.В. Языковое сознание как отражение этнокультурной реальности. Вопросы психолингвистики. 2003. № 1. С. 102-111.

Український форум лікарів [Електронний ресурс]. Режим доступу : http:// surgeryzone.net/ukr/index.php

Dijk, T.A. van. (1978). Cognitive psycologie and discourse: recalling and summarizing stories curent Trends in Textlinguistics. Berlin: Walter de Gruyter.

Donaldson, T. (1996). Values in Tension: Ethics Away from Home. Harvard Business Review, 5, 48-62. 
Здоров'я vs. хвороба в контексті словесної репрезентації иіннісної...

Green, D.W. (2014). Individual variability and neuroplastic changes. Applied Psycholinguistics, 5 (35), 910-912. doi: 10.1017/S0142716414000228

Gurevitch, M. (2000). Political Communication Systems and Democratic Values. Media Power in Politics. Washington, D.C.: CQ Press.

Lindsay, S. (2000). Culture, Mental Models, and National Prosperity. Culture Matters: how values shape human progress. New York: Basic Books.

Orman, J. (2016). Distributing mind, cognition and language: exploring the (un) common ground with integrational linguistics. Language and Cognition, 8 (1), 142-166. doi: 10.1017/langcog.2014.47

Saarni, S.I. (2011). Different methods for ethical analysis in health technology assessment: An empirical study. International Journal of Technology Assessment in Health Care, 4 (27), 305-312. doi: 10.1017/S026646231100044

Yancey, G.B. (2013). A Question of Values. Industrial and Organizational Psychology, 6 (3), 248-251. doi.org/10.1111/iops.12044

\section{References}

Anipkina, L.N. (2000). Otsenochnyie vyiskazyivaniya v pragmaticheskom aspekte [Appraisal in the pragmatic aspect]. Filologicheskie nauki-Philology, 2, 58-65 [in Russian].

Arutyunova, N.D. (1984). Aksiologiya $v$ mehanizmah zhizni i yazyika [Axiology in mechanisms of life and language]. (pp. 5-23). Moscow: Nauka [in Russian].

Arutyunova, N.D. (1988). Tipy yazykovykh znacheniy. Otsenka. Sobytiye. Fakt [Types of linguistic meanings. Appraisal. Existence. Fact.]. Moscow: Nauka [in Russian].

Balaban, O.O. (2017). Ponyattya mentalnoho leksykonu ta modeli orhanizatsiyi znan u pamyati lyudyny [The concept of the mental lexicon and the model of knowledge organization in the memory of man]. Psykholinhvityka - Psycholinguistics, 21 (2), 12-26 [in Ukrainian].

Baranov, A.N. (1989). Aksiologicheskie strategii v strukture yazyika (paremiologiya i leksika) [Axiological strategies in the structure of the language (paremiology and vocabulary)]. Voprosyi yazyikoznaniya - Topics in the study of language, 3, 74-90 [in Russian].

Baryishkov, V.P. (2005). Aksiologiya lichnostnogo byitiya [The axiology of personal being]. Moscow: Logos [in Russian].

Vdovichenko, L.V. (2010) «Poryadok» i «besporyadok» kak i antitsennost V politicheskom diskurse Rossii i SShA [«Order» and «disorder» as antivalue in the political discourse of Russia and the United States]. Politicheskaya lingvistika Political Linguistics, 33, 57-61 [in Russian].

Dementev, V.V. (2013). Kommunikativnyie tsennosti russkoy kulturyi : kategoriya personalnosti $v$ leksike i pragmatike [Communicative values of Russian culture: category of personality in vocabulary and pragmatics]. Moscow: Yazyiki slavyanskoy kulturyi [in Russian].

EKL, 2000. «Etychnyj kodeks likarja Ukrajiny» [Ethical Code of Ukrainian Doctor]. Medycyna transportu Ukrajiny - Medicine of Ukrainian transport, 4, 6-11 [in Ukrainian].

Ivin, A.A. (2006). Aksiologiya [Axiology]. Moscow: Vyisshaya shkola [in Russian].

Ihnatyeva, S.Ye. (2017). Funktsionalni osoblyvosti emotsiynoyi pamyati v strukturi shchodennykovoho dyskursu [Functional features of emotional memory in the structure of diary discourse]. Psykholinhvistyka - Psycholinguistics, 22 (2), 62-72 [in Ukrainian]. 
Health vs. Disease in the Context of Verbalization of the Axiological...

Ilin, V.V. (2005). Aksiologiya [Axiology]. Moscow: Izd-vo MGU [in Russian].

SUM (1970): Slovnyk ukrainskoi movy [Dictionary of the Ukrainian language]. (Vols. 11). Kyiv: Naukova dumka [in Ukrainian].

Kapanadze, L.A. (1988). Sposobyi vyirazheniya otsenki v ustnoy rechi [Ways of expressing an assessment in oral speech]. Raznovidnosti gorodskoy ustnoy rechiVariation in Urban Speech (pp. 151-156). Moscow: Nauka [in Russian].

Karasik, V.I. (2004). Aksiologicheskaya lingvistika: kontseptyi i diskurs [Axiological Linguistics: Concepts and Discourse]. Germanistika $v$ Rossii: traditsii $i$ perspektivyi - Germanism in Russia: Traditions and perspectives (pp. 28-32). Novosibirsk: Izd-vo NGU [in Russian].

Karasik, V.I. (1998). O kategoriyah diskursa [On the categories of discourse]. Yazyikovaya lichnost : sotsiolingvisticheskie $i$ emotivnyie aspektyi - Linguistic personality: sociolinguistic and emotional aspects (pp. 185-197). Volgograd : VGU; Saratov : SGU [in Russian].

Karasik, V.I (1996). Yazyikovaya lichnost : kulturnyie kontseptyi [Language personality: cultural concepts]. Volgograd, Arhangelsk: Peremena [in Russian].

Karaulov, Y.N. (1987). Russkiy yazyik $i$ yazyikovaya lichnost [Russian language and linguistic identity]. Moscow: Nauka [in Russian].

Kompantseva, L.F. (2018). Psykholinhvistychnyy opys tekhnolohichnoho dyskursu novykh media [Psychological and Linguistic Description of Technology Discourse of New Media]. Psykholinhvityka - Psycholinguistics, 23 (2), 120-131 [in Ukrainian]. doi.org/10.5281/zenodo.1208639

Kosmeda, T.A. (2000). Aksiologichni aspekti pragmalingvistiki: formuvannya i rozvitok kategoriyi otsinki [Axiological aspects of pragmalinguistics: formation and development of category of evaluation]. Lviv: Vidavnitstvo LNU im. I. Franka [in Ukrainian].

Krasnobaeva-Chorna, Zh.V. (2008). Diskursivna praktika [Discursive practice]. Donetsk: DonNU [in Ukrainian].

Krasnobaeva-Chorna, Zh.V. (2006). Terminopole kontsept [Terminopole concept]. Ukrayinska mova - Ukrainan language, 3, 67-79 [in Ukrainian].

Kuznetsova, T.V. (2010). Aksiologichni modeli mas-mediynoyi informatsiyi [Axiological models of mass media information]. Sumi: Universitetska kniga [in Ukrainian].

Kuznetsova, T.V. (2012). Mova yak determinant aksiolohichnoho balansu v informatsiynomu prostori [Language as the determinant of the axiological balance in the information space]. Psykholinhvityka - Psycholinguistics, 10, 286-294 [in Ukrainian].

Leschenko, T.O. (2017). Ukrayinska mova v meditsini [Ukrainian language in medicine]. Poltava: TOV «ASMI» [in Ukrainian].

Maslova, V.A. (2011). Kontseptyi i tsennosti: soderzhanie ponyatiy, yazyikovaya interpretatsiya [Concepts and values: the content of concepts, the language interpretation]. Uchenyie zapiski Tavricheskogo natsionalnogo universiteta im. V.I. Vernadskogo - Scientific notes of the Tavrida National University. V.I. Vernadsky, 2, 383-387 [in Russian].

Omelchenko, L.F. (2009). Aksiologichniy aspekt teleskopiyi v anglomovnomu diskursi [Axiological aspect of telescopy in English language discourse]. Inozemna filologiya - Foreign philology, 6, 13-26 [in Ukrainian].

Omelchenko, L.F. (2007). Kulturno-natsionalni konotatsiyi angliyskih kompozit [Cultural and national connotations of English composite]. Novitnya filologIya New Philology. (pp. 74-86). Mikolayiv: Vid. MDGU im. Petra Mogili [in Ukrainian]. 
Здоров'я vs. хвороба в контексті словесної репрезентації иіннісної...

Onischenko, I.V. (2005). Kategoriya otsinki ta zasobi yiyi virazhennya v publitsistichnih taitekstah [Category of evaluation and means of its expression in journalistic and informational texts]. Extended abstract of candidate's thesis. Dnipropetrovsk [in Ukrainian].

Ostrovska, O.M. (2001). Lingvostilistichni zasobi realizatsiyi kategoriyi otsinki (na materiali amerikanskoyi hudozhnoyi prozi) [Linguistic means of realization of the rating category (based on the material of the American artistic prose)]. Extended abstract of candidate's thesis. Lviv [in Ukrainian].

Slavova, L.L. (2012). Movna osobistIst lidera u dzerkali politichnoyi lingvopersonologIyi : SSHA - Ukrayina [The linguistic personality of the leader in the mirror of political lingvopsonology: USA - Ukraine]. Zhitomir : Vid-vo ZhDU im. I. Franka [in Ukrainian].

Svetonosova, T.A. (2006). Sopostavitelnoe issledovanie tsennostey v rossiyskom i amerikanskom politicheskom diskurse [Comparative study of values in Russian and American political discourse]. Candidate's thesis. Yekaterinburg [in Russian].

Slyishkin, G.G. (2001). Aksiologiya yazyikovoy lichnosti i sfera aksivnoy lingvistiki [Axiology of the linguistic personality and the sphere of the active linguistics]. Sotsialnaya vlast yazyika - Social power of the language. (pp. 53-64). Voronezh: Izd-vo VGU [in Russian].

Solovyova, L.F. (2001). Virazhennya aksiologichnih kategoriy u suchasniy angliyskiy movi (atributivi, predikativi i relyativi otsinki) [Expression of axiological categories in modern English (attributes, predicates and relativities of evaluation)]. Extended abstract of candidate's thesis. Kharkiv [in Ukrainian].

Taranenko, O.O. (2004). Formuvannya novoyi sistemi sotsialnih tsinnostey i prioritetiv ukrayinskogo suspilstva (na materialah ukrayinskoyi movi kintsya XX pochatku XXI st.) [Formation of a new system of social values and priorities of Ukrainian society (on materials of the Ukrainian language of the late XX - early XXI centuries)]. Movoznavstvo - Linguistics, 3, 3-33 [in Ukrainian].

Frumkina, R.M. (2001). Psiholingvistika [Psycholinguistics]. Moscow: Nauka [in Russian].

Ufimtseva, N.V. (2003). Yazyikovoe soznanie kak otrazhenie etnokulturnoy realnosti [Language consciousness as a reflection of ethnocultural reality. Journal of Psycholinguistics]. Voprosyi psiholingvistiki - Journal of Psycholinguistics, 1, 102-111 [in Russian].

Ukrayinskiy forum likariv [Ukrainian forum of doctors]. URL: http://surgeryzone.net/ ukr/index.php [in Ukrainian].

Dijk, T.A. van. (1978). Cognitive psycologie and discourse: recalling and summarizing stories curent Trends in Textlinguistics. Berlin: Walter de Gruyter.

Donaldson, T. (1996). Values in Tension: Ethics Away from Home. Harvard Business Review, 5, 48-62.

Green, D.W. (2014). Individual variability and neuroplastic changes. Applied Psycholinguistics, 5 (35), 910-912. doi: 10.1017/S0142716414000228

Gurevitch, M. (2000). Political Communication Systems and Democratic Values. Media Power in Politics. Washington, D.C.: CQ Press.

Lindsay, S. (2000). Culture, Mental Models, and National Prosperity. Culture Matters: how values shape human progress. New York: Basic Books.

Orman, J. (2016). Distributing mind, cognition and language: exploring the (un) common ground with integrational linguistics. Language and Cognition, 8 (1), 142-166. doi: 10.1017/langcog.2014.47 
Health vs. Disease in the Context of Verbalization of the Axiological...

Saarni, S.I. (2011). Different methods for ethical analysis in health technology assessment: An empirical study. International Journal of Technology Assessment in Health Care, 4 (27), 305-312. doi: 10.1017/S026646231100044

Yancey, G.B. (2013). A Question of Values. Industrial and Organizational Psychology, 6 (3), 248-251. doi.org/10.1111/iops. 12044

\section{АНОТАЦІЯ}

Статтю присвячено проблемі інтерпретації цінностей та антицінностей у лінгвістичному контексті. Акцентовано на релевантності вирізнення дихотомії цінність - антицінність (нецінність). Визначено, що цінності - це сукупність життєво необхідних матеріальних та духовний понять, які окреслюють базові поведінкові домінанти людини, забезпечують ії основні інтереси та найважливіші потреби. Антицінності дефіновано опозиційною (за смислом) до цінностей універсальною категорією загальної аксіологічної парадигми людини.

Простежено значущість студіювання аксіологічного лікарського континууму, представленого в дискурсі. Проаналізовано ціннісні аспекти медичної комунікації. У пропонованій праці вирізнено ключові семантичні опозиції - здоров'я - хвороба, які за результатами аналізу посідають чільне місце в аксіологічній картині світу сучасного лікаря та займають протилежні позиції на осі цінність - антицінність.

Обгрунтовано думку про те, що цінність для лікаря - це те, на що скерована його робота як компетентного фахівия медичної галузі, а також важливий атрибут його свідомості, який виформовує вектори професійної діяльності.

Виділено в обстеженому дискурсі мовні рефлекси вказаних ціннісних орієнтирів сучасного лікаря. Описано закономірності мовної об'єктивації протилежних аксіологічних орієнтирів - здоров'я та хвороби, які увиразнюють функціонування всіх живих організмів, зокрема й людей, на векторі життя - смерть. Зауважено, що всі проаналізовані словесні об'єктиватори відображають модифікацію аксіологічної парадигми в галузі охорони здоров'я.

Крім цього, указано на прагматичний потенціал лексем, що вербалізують ціннісний континуум медичної комунікації. Зафіксовані в дискурсі позитивно і негативно конотовані лексеми увиразнюють схвалення, привітність, докір чи критичне ставлення лікаря до пацієнтів.

Ключові слова: аксіологічна лінгвістика, цінність, антицінність, медичний дискурс, лікар, здоров'я, хвороба. 
Здоров’я vs. хвороба в контексті словесної репрезентації изіннісної...

Лещенко Татьяна, Жовнир Марина. Здоровье vs. болезнь в контексте словесной репрезентации ценностной картины мира современного доктора

\section{АННОТАЦИЯ}

Статья посвящена проблеме интерпретации ценностей и антиценностей в лингвистическом контексте. Указано на релевантность установления дихотомии ценность - антиценность (неценность). Определено, что ценности - это совокупность жизненно важных материальных и духовных понятий, которые и определяют базовые поведенческие доминанты человека, обеспечивают его основные интересы и потребности. Антиценности дефинированы оппозиционной (по смыслу) к ценностям универсальной категорией общечеловеческой аксиологической парадигмы.

Рассматривая ценностные аспекты медицинской коммуникации, особое внимание уделяется необходимости изучения представленого в дискурсе аксиологического континуума доктора. В представленной работе определены ключевые семантические оппозиции - здоровье и болезнь, которые по результатам анализа занимают центральное место в аксиологической картине мира современного доктора и располагаются в противоположных точках системы координат ценность - антиценность.

Обосновано мнение о том, что ценность для врача - это то, на что направлена его работа как компетентного специалиста медицинской отрасли, существенный атрибут сознания, который определяет векторы профессиональной деятельности доктора.

Исследование дискурсивно-текстового материала позволило определить языковые рефлексы указанных ценностных ориентиров. В работе представлены особенности языковой объективации противоположных аксиологических ориентиров - здоровья и болезни. Указано, что все проанализированные словесные объективаторы отражают модификацию парадигмы в области здравоохранения.

Кроме этого, отмечен прагматический потенциал лексем, которые вербализируют ценностный компонент медицинской коммуникации. Зафиксированные в дискурсе положительно и отрицательно коннотированные лексемы выражают одобрения, приветливость, упрек или критическое отношение доктора к пациентам.

Ключевые слова: аксиологическая лингвистика, ченность, антиценность, медицинский дискурс, доктор, здоровье, болезнь. 